BRITISH MEDICAL JOURNAL VOLUME $294 \quad 20$ JUNE 1987

discharge, our results indicate that the optimum time to measure serum lipid concentrations in such patients is immediately on admission. In addition, these findings have implications for research-for example, they attest to the validity of measuring total serum cholesterol concentrations soon after myocardial infarction in case-control studies of coronary heart disease.

1 Fyfe T, Baxter RH, Cochran KM, Booth EM. Plasma-lipid changes after myocardial infarction. Lancet 1971;ii:997-1001.

2 Ryder RE, Hayes TM, Mulligan IP, Kingswood JC, Williams S, Owens DR. How soon after Ryder RE, Hayes TM, Mulligan IP, Kingswood JC, Williams S, Owens DR. How soon
myocardial infarction should plasma lipid values be assessed? Br Med J 1984;289:1651-3.

3 Gore JM, Goldberg RJ, Matsumoto AS, et al. Validity of serum total cholesterol level obtained within 24 hours of acute myocardial infarction. Am J Cardiol 1984;54:722-5.

(Accepted 26 March 1987)

Department of Community Health and General Practice, University of Auckland, Private Bag, Auckland, New Zealand

RODNEY JACKSON, MB, CHB, National Heart Foundation research fellow in epidemiology

ROBERT SCRAGG, MB, PHD, epidemiologist

ROGER MARSHALL, PHD, statistician

Department of Cardiology, Greenlane Hospital, Auckland

HARVEY WHITE, FRACP, National Heart Foundation senior fellow in cardiology

Department of Cardiology, Auckland Hospital, Auckland

KEVIN O'BRIEN, FRACP, cardiologist

Department of Clinical Biochemistry, Greenlane Hospital, Auckland

CHARLES SMALL, PHD, MAACB, biochemist

Correspondence and requests for reprints to: Dr Jackson.

\section{Severe rectal bleeding due to Salmonella paratyphi B}

Lifethreatening rectal haemorrhage is rare. The commonest causes are diverticular disease, colonic angiodysplasia, Meckel's diverticulum, peptic ulceration in the stomach or duodenum, and trauma. We present a case of massive colonic and rectal bleeding due to Salmonella paratyphi B that required emergency colectomy.

\section{Case report}

An 18 year old girl presented with a two hour history of bleeding from the rectum. This followed a two week illness similar to flu, four days of constipation, and then diarrhoea. There was no relevant medical or drug history. On admission she was shocked and feverish $\left(39 \cdot 6^{\circ} \mathrm{C}\right)$ with pulse 120 beats $/ \mathrm{min}$ and blood pressure $100 / 60 \mathrm{~mm} \mathrm{Hg}$. There were no abnormal signs, but rectal examination showed fresh clots of blood.

Despite active resuscitation her condition remained critical. Her haemoglobin concentration was $40 \mathrm{~g} / \mathrm{l}$, but all other tests including coagulation studies yielded normal results. Findings on gastroscopy were normal. Superior and inferior mesenteric arteriograms showed no evildence of bleeding. Colonoscopy was unsuccessful because of the profuse haemorrhage. A scan using red cells tagged with technetium- $99 \mathrm{~m}$ showed pooling of blood only in the colon, and at laparotomy only the left colon was affected. Colotomy showed bleeding from innumerable shallow ulcers. Extended left hemicolectomy and end colostomy were performed. Continued bleeding from the ulcerated mucosa in the rectal stump required an underrunning suture and packing of the rectum. She received a total of 26 litres of blood and plasma.

Culture of a stool specimen showed Salmonella paratyphi B (phage type Dundee). There were innumerable superficial ulcers $1-12 \mathrm{~mm}$ in diameter in the colon, their severity increasing distally (figure). Histologically the ulcers were characterised by a paucity of neutrophils in the granulation tissue and exudate. The colonic lymphoid aggregates contained many plump histiocytes, some containing debris ("typhoid cells"); similar cells were present in the dilated sinuses of the draining lymph nodes. No vasculitis was seen.

Postoperatively no further complications occurred. The rectal pack was removed after 72 hours and chloramphenicol $50 \mathrm{mg} / \mathrm{kg}$ given for 10 days. The colostomy was closed uneventfully two months later.

\section{Comment}

Paratyphoid B is the commonest enteric fever in western Europe and is more commonly acquired by ingestion of infected food than contaminated water. Postoperatively this patient said that she had eaten a hamburger in a seaside resort two weeks before her admission; this incubation time is consistent with paratyphoid fever.

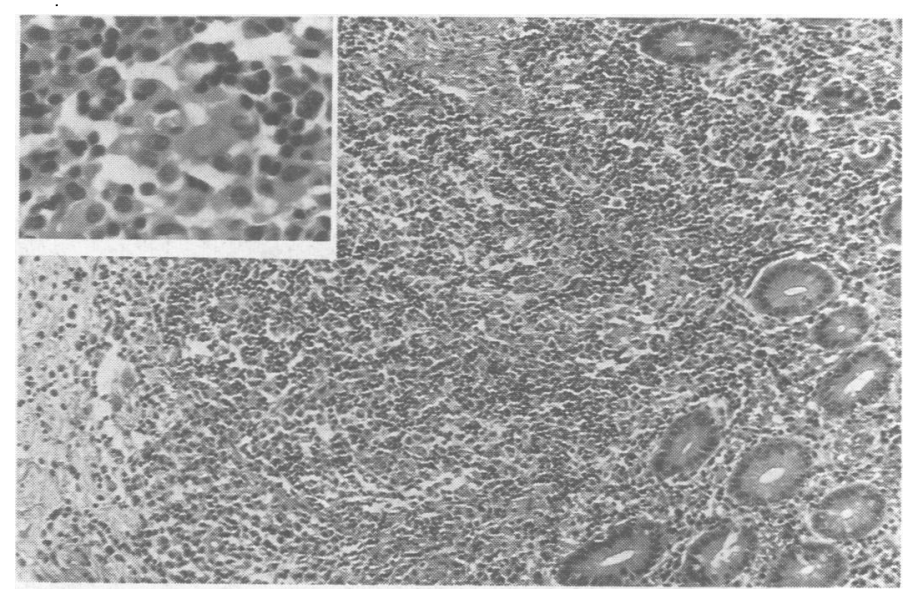

Colonic mucosa and submucosa (haematoxylin and eosin); lymphoid aggregate showing typical histiocytes with abundant cytoplasm and eccentric small nuclei. Inset shows histiocytes containing phagocytosed material (so called "typhoid cells"). Similar cells were observed in sinuses of draining lymph nodes.

The methods available for identifying sites of bleeding in the gastrointestinal tract have limitations. Angiography failed to identify the nature of the colonic and rectal haemorrhage in this case, which highlights its inadequacy when there are multiple bleeding sites that individually bleed less than $3 \mathrm{ml}$ per minute, but together produce extensive blood loss. ${ }^{1}$ The usefulness of scanning with red cells labelled with technetium in detecting the site of bleeding can be limited by blood background activity as there must be a sufficient difference between the levels of circulating and extravasated tracer for the bleeding to be localised reliably. ${ }^{2}$ It is important to exclude a cause in the upper gastrointestinal tract by endoscopy. Preoperative colonoscopy in these cases, however, is difficult because of the large amounts of clotted blood in unprepared bowel. In retrospect peroperative colonoscopy after colonic lavage might have provided valuable information in this case and is a useful investigation in massive colonic haemorrhage.

Ulceration of the gastrointestinal tract in paratyphoid fever is usually limited to the terminal ileum, ${ }^{3}$ sometimes leading to the passage of traces of blood through the rectum and even severe bleeding. Intestinal haemorrhage is a rare complication, occurring in $1 \%$ of cases ${ }^{4}$ We can find no reports of a case similar to ours.

We thank Mr Max Rendall for permission to report this case.

1 Sutton D. A textbook of radiology and imaging. London: Churchill Livingstone, 1980.

2 Braunstein P, Song CS. The uses and limitations of radioisotopes in the investigation of gastrointestinal diseases. American foumal of Digestive Diseases 1975;20:53-90.

3 Morson BC, Dawson IMP. Alimentary system. In: Symmers WStC, ed. Systemic pathology. Vol 3. London: Churchill Livingstone, 1978:1068.

4 Gadenholt H, Madren ST. Clinical course, complications and mortality in typhoid fever as compared with paratyphoid B. A survey of 2647 cases. Acta Med Scand 1963;174:753.

(Accepted 18 March 1987)

Department of Surgery, Guy's Hospital, London SE1 9RT

J A SPENCE, BSC, MB, house surgeon

R MOGERE, FRCS, surgical registrar

T J PALMER, MRCP, MRCPATH, senior registrar in clinical microscopy

P H ROWE, MA, FRCS, senior surgical registrar

Correspondence to: $\mathrm{Mr}$ Rowe. 